\title{
Analiza zjawiska odspajania katodowego powłoki na podstawie badań terenowych oraz badań laboratoryjnych
}

\author{
Cathodic disbondment of coating on the basis of field and laboratory tests - phenomenon \\ analysis
}

\author{
Paweł Stochaj \\ Instytut Nafty i Gazu - Państwowy Instytut Badawczy
}

\begin{abstract}
STRESZCZENIE: W artykule omówiono wyniki uzyskane podczas badań laboratoryjnych i terenowych zjawiska odspajania katodowego powłoki pod wpływem nadmiernej polaryzacji katodowej. Zjawisko to podczas nadmiernej polaryzacji gazociągów może być przyczyną naruszenia integralności gazociągu. W wyniku odspajania powłoki w miejscu defektu pod powierzchnię powłokową dostaje się elektrolit, który w wyniku niekorzystnego nadmiernego oddziaływania ochrony katodowej w miejscu defektu powłoki ułatwia dalsze niekontrolowane jej odspajanie. Prąd ochrony katodowej w wyniku powiększania się powierzchni defektu pod powłoką ma utrudniony dostęp, przez co w miejscu defektu nie może być zapewniona skuteczna ochrona. Do badań wybrano 6 powłok wytwarzanych w kraju, które najczęściej stosuje się w czasie eksploatacji w różnych warunkach terenowych. W celu przeprowadzenia badań na terenie Instytutu Nafty i Gazu wykonano stanowisko terenowe, na którym zainstalowano 42 próbki do badań, które podłączono do instalacji ochrony katodowej. Do wykonania badań laboratoryjnych zaprojektowano i wykonano stanowisko, które wyposażono w odpowiedni sprzęt badawczy. Opracowano harmonogram badań, który obejmował przeprowadzenie badań w czasie 24 miesięcy w latach 2016 do 2018. Podczas badań na stanowisku terenowym i laboratoryjnym regularnie kontrolowano parametry polaryzacji. W czasie 24 miesięcy badań zgodnie z harmonogramem próbki do badań były wyciągane z ziemi i poddawane szczegółowym oględzinom. Następnie próbki badano na wielkość odspojenia katodowego, a uzyskane wyniki badań wstępnie analizowano i archiwizowano. Uzyskane wyniki badań laboratoryjnych porównano z wynikami badań terenowych. Przedstawiono analizę i omówiono otrzymane wyniki badań. $\mathrm{Z}$ analizy wyników badań wyciągnięto wnioski. W artykule zawarto wniosek, że zjawisko odspajania katodowego jest silnie związane z rodzajem powłoki oraz jakością przygotowania powierzchni stalowej rury przed nałożeniem powłoki.
\end{abstract}

Słowa kluczowe: potencjał, odspajanie katodowe, badania terenowe, badania laboratoryjne.

ABSTRACT: The article discusses the results of tests obtained during laboratory and field tests of cathodic disbondment under the influence of excessive cathodic polarization. This phenomenon, during over-polarization of gas pipelines, may be a reason to breach the integrity of the gas pipeline. As a result of disbondment of the coating in the place of the defect, an electrolyte gets underneath the surface of the coating, which due to the unfavorable excessive influence of cathodic protection in the place of the defect of the coating facilitates further uncontrolled detachment. The cathodic protection current, as a result of the enlargement of the defect surface under the coating, has difficult access, which means that its effective protection cannot be ensured in the place of the defect. Six coatings manufactured in the country were selected for the tests, which are most often used during operation in various field conditions. In order to carry out the tests, a field station was made on which 42 test samples were installed, which were connected to the cathodic protection installation. A station was designed and constructed to perform laboratory tests, which were equipped with appropriate research equipment. A research schedule was prepared, which included testing within 24 months in 2016 to 2018. During field and laboratory tests, polarization parameters were regularly monitored. The obtained results of laboratory tests were compared with the results of field tests. During the 24 months of testing according to the schedule, the test samples were taken out of the ground and subjected for detailed inspection. The samples were then tested for cathodic disbondment, and the obtained test results were initially analyzed and archived. The obtained results of laboratory tests were compared with the results of field tests. The analysis was presented and the obtained test results were discussed. The analysis of the research results drew conclusions. The paper concludes that the phenomenon of cathodic disbondment is strongly associated with the type of coating and the quality of surface preparation of the steel pipe before applying the coating.

Key words: potential, cathodic disbondment, field tests, laboratory tests.

Autor do korespondencji: P. Stochaj, e-mail: pawel.stochaj@inig.pl

Artykuł nadesłano do Redakcji 11.01.2019 r. Zatwierdzono do druku 12.07.2019 r. 


\section{Wstęp}

W czasie normalnej eksploatacji gazociągów umieszczonych w ziemi, które zabezpiecza się przed niepożądanym wpływem czynników zewnętrznych powłokami izolacyjnymi, dochodzi do powstawania na ich powierzchni defektów powłoki. Elektrolit glebowy w kontakcie z eksponowaną powierzchnią stali w miejscu defektu może stworzyć zagrożenie korozyjne w postaci miejscowej korozji. Aby zabezpieczyć miejsca defektów przed korozją, stosuje się na gazociągach ochronę katodową, która współpracuje z powłoką izolacyjną gazociągu. Nadmierna polaryzacja katodowa w miejscu defektu może stać się źródłem korozji i być przyczyną poważnej awarii oraz naruszyć integralność gazociągu. Pod pojęciem integralność gazociągu rozumie się taki jego stan techniczny, który pozwala na bezpieczny i ciągły przesył gazu (Dietrich, 2009). Starzejące się gazociągi stwarzają potencjalne ryzyko awarii, które nie może być całkowicie wyeliminowane (Dietrich, 2009).

Odspajanie katodowe powłoki jest procesem bardzo niebezpiecznym. $Z$ jednej strony operator rurociągu chce go zabezpieczyć w sposób trwały, pokrywając go warstwami powłok izolacyjnych, które mają na celu chronić go przed czynnikami takimi jak elektrolit glebowy, mogący bezpośrednio wpłynąć na stan rurociągu. $\mathrm{Z}$ drugiej strony działanie izolacyjne powłok dodatkowo uzupełnia jeszcze ochrona katodowa, której zadaniem jest zabezpieczyć miejsca nieciągłości powłoki. Ochrona katodowa w miejscach defektów powłoki ma spowodować, że szybkość korozji zostanie zmniejszona lub zatrzymana całkowicie (Baeckmann et al., 1997). Jednak zbyt duża polaryzacja katodowa rurociągu może spowodować odspojenie katodowe powłoki. Zjawisko to jest niebezpieczne, a operator rurociągu może nie mieć odpowiedniej wiedzy o skali zagrożenia.

W 2016 roku podjęto decyzję o przeprowadzeniu w ramach pracy statutowej analizy wyników badań zjawiska odspajania katodowego w wyniku nadmiernej polaryzacji katodowej stali. Badania zostały wykonane na nowo zbudowanym stanowisku laboratoryjnym oraz na specjalnie do tego celu zbudowanym stanowisku terenowym na terenie Instytutu Nafty i Gazu Państwowego Instytutu Badawczego przy ulicy Bagrowej. Harmonogram badań został opracowany na 24 miesiące badań, które zakończyły się analizą otrzymanych wyników.

\section{Odspajanie katodowe powłoki izolacyjnej}

Zjawisko odspajania powłoki izolacyjnej od rurociągu występuje, gdy nadmierną polaryzację rurociągu utrzymuje się zbyt długo bez kontroli. Nadmierna polaryzacja powoduje wydzielenie się, pod wpływem przepływającego prądu (ochrony katodowej), z elektrolitu do defektu powłoki produktów reakcji katodowej redukcji, które pojawiają się na powierzchni defektu. $Z$ biegiem czasu, gdy potencjał ochrony rurociągu w niekontrolowany sposób wzrasta w kierunku elektroujemnym, następuje uwolnienie się w bezpośredniej bliskości brzegu defektu wodoru, który doprowadzi do powolnego odspajania powłoki. Wielkość prądu jest zależna od wielkości defektu, przez jaki przepływa. Wraz ze wzrostem wielkości defektu powłoki izolacyjnej zwiększa się ilość prądu przepływającego przez defekt, a na granicy faz powłoka-powierzchnia metalu następuje odrywanie powłoki.

Szybkość odspajania jest zależna od polaryzacji katodowej stali, jakości i grubości powłoki oraz środowiska elektrolitycznego, w jakim defekt się znajduje. Do powoli powiększającej się przestrzeni pomiędzy oderwaną powłoką a metalową powierzchnią rury zaczyna napływać elektrolit, powiększając tym samym powierzchnię defektu, który w późniejszym czasie jest źródłem korozji.

W następstwie tego procesu prąd ochrony katodowej będzie docierał do bezpośrednio eksponowanej powierzchni defektu, a nie w coraz to dalsze miejsca pod odspajaną powłokę izolacyjną. Na rysunku 1 przedstawiono przykładowy defekt o kształcie kołowym (zaznaczony grubą linią) powłoki izolacyjnej i możliwe kierunki (strzałki) powiększania się defektu pod powłoką izolacyjną oraz przykładową fotografię.

Linią przerywaną zaznaczono możliwe wielkości powiększania się defektów pod powłoką wraz z upływem czasu przy eksploatacji rurociągu z nadmierną polaryzacją ochrony
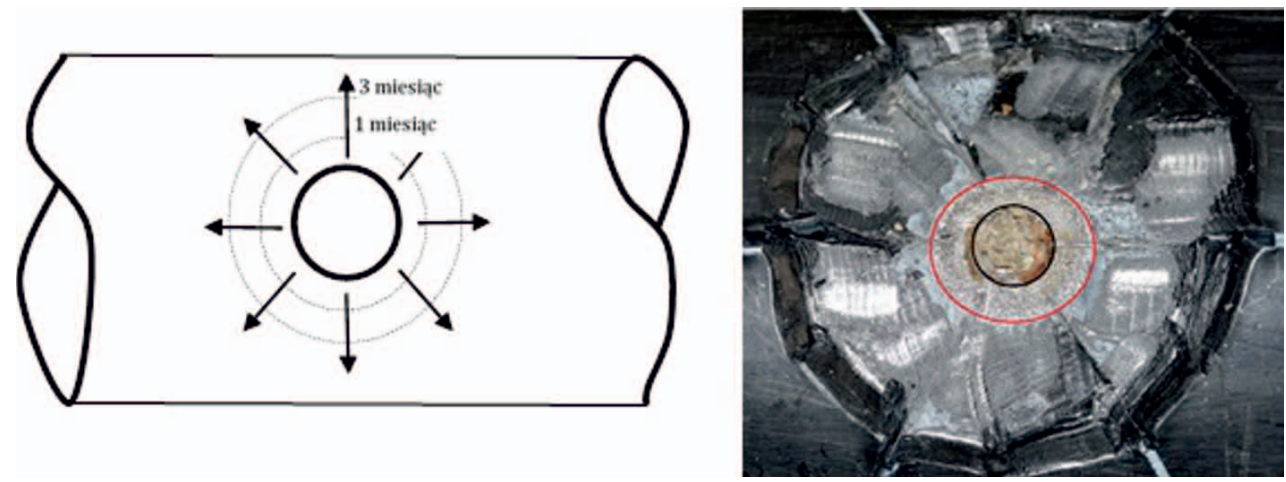

Rys. 1. Kolejne etapy odspajania się powłoki izolacyjnej pod defektem w wyniku nadmiernej katodowej polaryzacji. Na fotografii zaznaczono czerwonym okręgiem obszar odspojenia powłoki poza pierwotny obszar defektu

Fig. 1. Subsequent stages of disbondment of the insulating coating under the defect as a result of excessive cathodic polarization. In the photograph, the red circle is marked by the area of the shell being separated from the primary area of the defect 
katodowej. Oczywiście w przypadku defektów liniowych, na przykład pęknięć czy też zadrapań, które mogły powstać z winy osób trzecich podczas budowy lub w czasie eksploatacji, powiększający się defekt może mieć całkiem inny kształt. Uszkodzona powłoka może w różnych miejscach mieć różną przyczepność, co może wpływać na kształt i powierzchnię defektu odspajanej powłoki. Również umiejscowienie defektu na rurze, na przykład na powierzchni pionowej rury, może spowodować, że kierunek odspajania powłoki izolacyjnej przy defekcie będzie skierowany w dół.
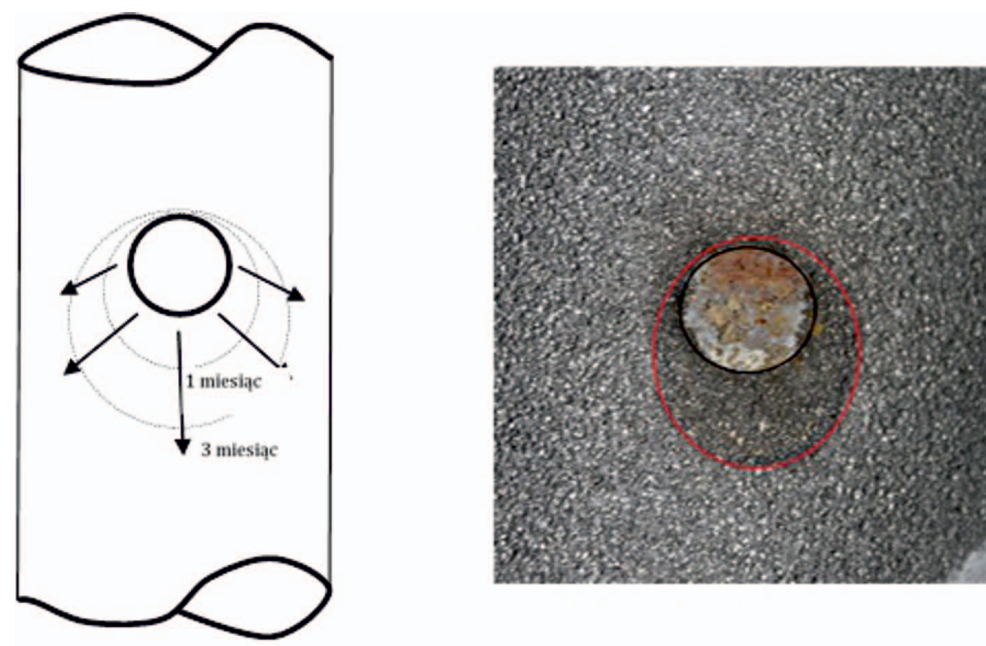

Rys. 2. Przykład nierówno odspajanej powierzchni stali pod defektem znajdującym się na pionowym odcinku rury. Na fotografii zaznaczono czerwonym okręgiem obszar odspojenia powłoki poza pierwotny obszar defektu

Fig. 2. An example of unevenly disbondment steel surface under a defect placed on the vertical section of the pipe. In the photograph, the red circle is marked by the area of the shell being separated from the primary area of the defect

Na rysunku 2 przedstawiono defekt kołowy, na którym zaznaczono liniami przerywanymi oraz strzałkami możliwy kierunek odspajania katodowego. Na fotografii zaznaczono czerwonym okręgiem kierunek i obszar odspajania powłoki. Na zdjęciu doskonale widać nierównomierne odspajanie powłoki pomiędzy zaznaczonymi na czerwono i czarno okręgami. Większe odspajanie wystąpiło w kierunku pionowym, w którym rura $\mathrm{z}$ defektem $\mathrm{w}$ powłoce została umiejscowiona. Ten przykład jest świadectwem, że elektrolit w powłoce może migrować w różnych kierunkach, a powodem tego nie musi być zła jakość powłoki czy też słabe przyleganie powłoki do powierzchni stalowej rury, ale siła grawitacji, która może spowodować obranie kierunku migracji przez elektrolit.

Przyczyną nadmiernej polaryzacji katodowej, w wyniku której może wystąpić zjawisko odspajania katodowego powłoki, może być nie tylko źle ustawiona ochrona katodowa. Powodem mogą być również prądy błądzące pochodzące od linii wysokiego napięcia oraz występujące w miejscach skrzyżowań z elektryfikowanymi liniami kolejowymi lub tramwajowymi, gdzie w miejscach wpływu prądu błądzącego do defektu wzmacnia się efekt polaryzacji katodowej.

\section{Warunki badań}

W latach 2016-2018 wykonano badania wielkości odspajania katodowego dla powłok 3LPE, 3LPP, PUR, TERM (powłoka z materiałów termokurczliwych), B30 i C30 (powłoki z taśm nawojowych). Wszystkie wykonane badania na stanowisku laboratoryjnym zostały przeprowadzone zgodnie z warunkami badań, które zawarte są w odpowiedniej dla danego typu powłoki normie. Powłoki 3LPE i 3LPP zostały przebadane zgodnie z PN-EN ISO 21809-1:2011, powłoka PUR została przebadana zgodnie z PN-EN 10290:2005, a powłoki TERM, B30 i C30 zostały przebadane zgodnie z PN-EN 12068:2002.

W badaniach użyto próbek z odcinków rur dostarczonych przez producentów poszczególnych powłok, które zostały przeznaczone do badań laboratoryjnych i terenowych. Do badań laboratoryjnych wykorzystano próbki o długości około $0,3 \mathrm{~m}$, które przygotowano do badań zgodnie z warunkami badań określonymi w odpowiedniej normie dla danego typu powłoki. Badania terenowe przeprowadzono na stanowisku terenowym na terenie Instytutu Nafty i Gazu - Państwowego Instytutu Badawczego. Do badań użyto próbek o długości 1 metra ze sztucznie naniesionymi defektami powłoki. Na każdej próbce wykonano po 3 defekty w powłoce izolacyjnej o średnicy $1 \mathrm{~cm}$. Próbki połączono z instalacją ochrony katodowej, a po zainstalowaniu w ziemi polaryzowano je do potencjału $1500 \pm 10 \mathrm{mV}$. Zastosowanie w badaniach jednakowego poziomu potencjału polaryzacji zapewniło takie same warunki narażania próbek podczas badań laboratoryjnych i terenowych. Podczas badań terenowych warunki badań dla wszystkich próbek były takie same. Pomiary $\mathrm{pH}$ i rezystywności gruntu w miejscach zainstalowania próbek wykazały niewielkie różnice, na poziomie $0,5 \%$, co jest wartością małą, niemającą wpływu na wyniki badań.

Badania na stanowisku laboratoryjnym rozpoczęto pod koniec stycznia 2017 roku. Do grudnia 2017 roku wykonano 3 serie badań laboratoryjnych, z których uzyskano wyniki wielkości odspajania katodowego dla każdej powłoki wytypowanej do badań. W czasie badań laboratoryjnych pod koniec 2017 roku po wstępnej analizie wyników badań podjęto decyzję, aby wydłużyć badania o czwartą, dodatkową serię badawczą, w której wydłużono okres badań do 3 miesięcy.

Badania na stanowisku terenowym rozpoczęto 14 września 2016 roku i trwały one do 14 września 2018 roku. 


\section{Omówienie wyników badań}

Na rysunku 3 przedstawiono średnie wyniki badań terenowych odspajania katodowego dla poszczególnych badanych typów powłok.

Badania terenowe powłok w czasie 24 miesięcy wykazały stały wzrost wartości odspajania katodowego. W przypadku powłok 3LPE, 3LPP, PUR pierwszy miesiąc badań nie wykazał żadnego zjawiska odspajania katodowego powłoki.

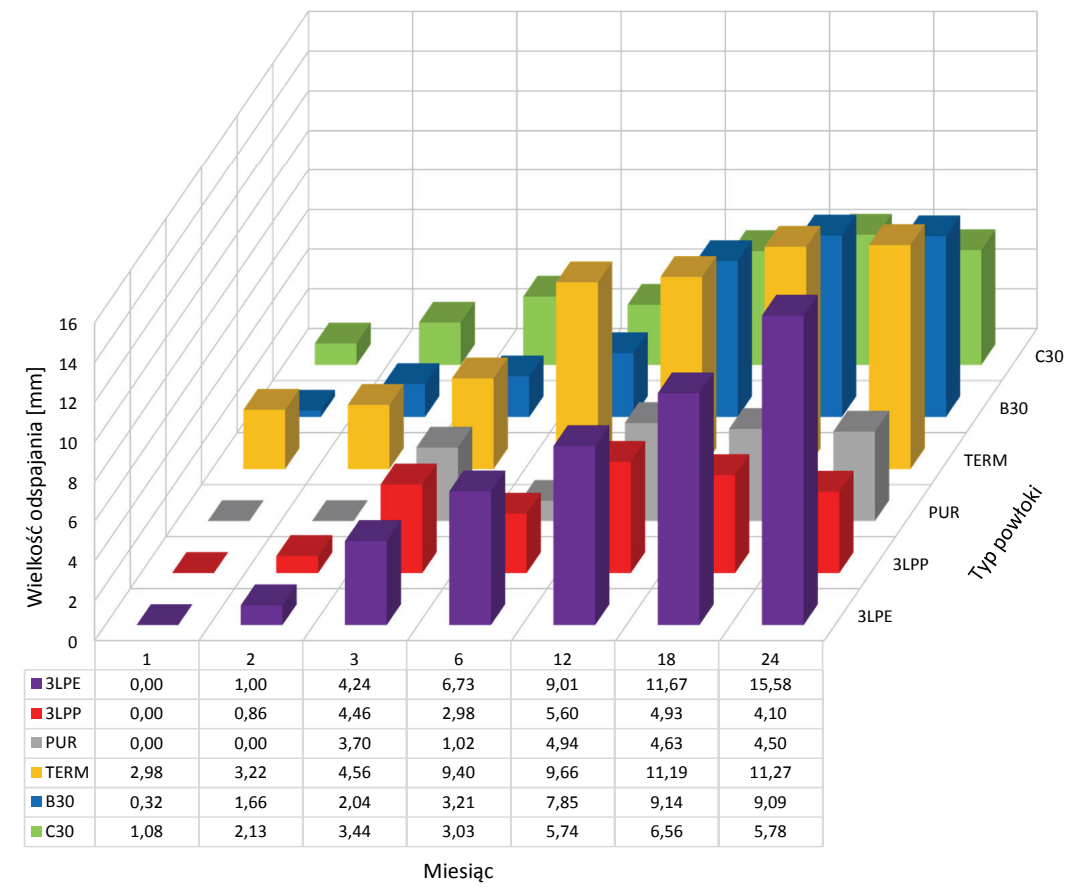

Rys. 3. Średnie wyniki badań terenowych odspajania katodowego dla poszczególnych typów badanych powłok uzyskane w ciągu 24 miesięcy badań

Fig. 3. The average results of field tests of cathodic disbondment for particular types of tested coatings obtained during 24 months of research
Ponadto na powłoce PUR w 2. miesiącu badań również nie stwierdzono żadnej wartości wielkości odspajania. Świadczy to o bardzo dobrej odporności tych powłok (nałożonych na badanych próbkach) na odspajanie katodowe w defektach tych powłok w początkowym okresie badań, od około 1 do 2 miesięcy badań terenowych. Powłoki TERM, B30 i C30 nałożone na badane próbki już na początku badań terenowych wykazały zdolność do łatwego odspajania katodowego powłoki, a szczególnie powłoka TERM, która cechowała się najniższą odpornością na odspajanie katodowe.

W tabeli 1 przedstawiono wyniki badań laboratoryjnych po 28 dniach i po 3 miesiącach badań. Ponadto zawarto w niej przybliżony czas uzyskania wartości odspajania katodowego dla badań terenowych porównanych do wyników badań laboratoryjnych otrzymanych po 28 dniach oraz po 3 miesiącach badań laboratoryjnych.

Jak wynika z tabeli 1 oraz rysunku 3 wyniki badania w warunkach laboratoryjnych po 28 dniach badań są porównywalne tylko do wyników badań terenowych powłok typu 3LPE, 3LPP i TERM. Powłoki PUR, B30 i C30 nie uzyskały zbieżnych wyników po 28-dniowych badaniach laboratoryjnych i 24-miesięcznych badaniach terenowych. Po rozszerzeniu czasu badań laboratoryjnych do 3 miesięcy otrzymano wyniki badań porównywalne dla powłok $3 \mathrm{LPE}$, 3LPP, TERM i 30. Dla powłok PUR i B30 nie zdołano uzyskać zbieżnych wyników badań.

$\mathrm{Na}$ rysunku 4 przedstawiono średnie wartości odspajania katodowego uzyskane podczas 28-dniowych badań laboratoryjnych i 24-miesięcznych badań terenowych.

Tabela 1. Wyniki badań dla poszczególnych serii badawczych uzyskane podczas badań laboratoryjnych odporności powłoki izolującej na odspajanie katodowe

Table 1. Test results for individual test series obtained during laboratory tests of the resistance of the insulating coating to cathodic disbondment

\begin{tabular}{|c|c|c|c|c|c|}
\hline $\begin{array}{c}\text { Typ } \\
\text { powloki }\end{array}$ & $\begin{array}{c}\text { Średnia wartość } \\
\text { odspajania katodowego } \\
\text { po 28-dniowych bada- } \\
\text { niach laboratoryjnych }\end{array}$ & $\begin{array}{l}\text { Przybliżony czas } \\
\text { uzyskania wartości } \\
\text { odspajania katodowego } \\
\text { dla badań terenowych } \\
\text { w porównaniu do } \\
\text { 28-dniowych badań } \\
\text { laboratoryjnych }\end{array}$ & $\begin{array}{c}\text { Średnia wartość } \\
\text { odspajania katodowego } \\
\text { po 3-miesięcznych bada- } \\
\text { niach laboratoryjnych }\end{array}$ & $\begin{array}{l}\text { Przybliżony czas } \\
\text { uzyskania wartości } \\
\text { odspajania katodowego } \\
\text { dla badań terenowych } \\
\text { w porównaniu do } \\
\text { 3-miesięcznych badań } \\
\text { laboratoryjnych }\end{array}$ & $\begin{array}{c}\text { Dopuszczalna } \\
\text { wartość } \\
\text { odspojenia } \\
\text { katodowego }\end{array}$ \\
\hline & [mm] & [miesiąc] & [mm] & [miesiąc] & {$[\mathrm{mm}]$} \\
\hline $3 \mathrm{LPE}$ & 4,80 & $3,0-3,5$ & 13,87 & 21,0 & $\leq 7$ \\
\hline 3LPP & 2,41 & 2,5 & 2,88 & 2,5 & $\leq 7$ \\
\hline PUR & 5,62 & - & 12,35 & - & $\leq 8$ \\
\hline TERM & 8,53 & 5,0 & 8,59 & 5,0 & $\leq 20$ \\
\hline B30 & 0,20 & - & 9,79 & - & $\leq 20$ \\
\hline C30 & 0,67 & - & 4,86 & $9,5-10,0$ & $\leq 20$ \\
\hline
\end{tabular}




\section{NAFTA-GAZ}

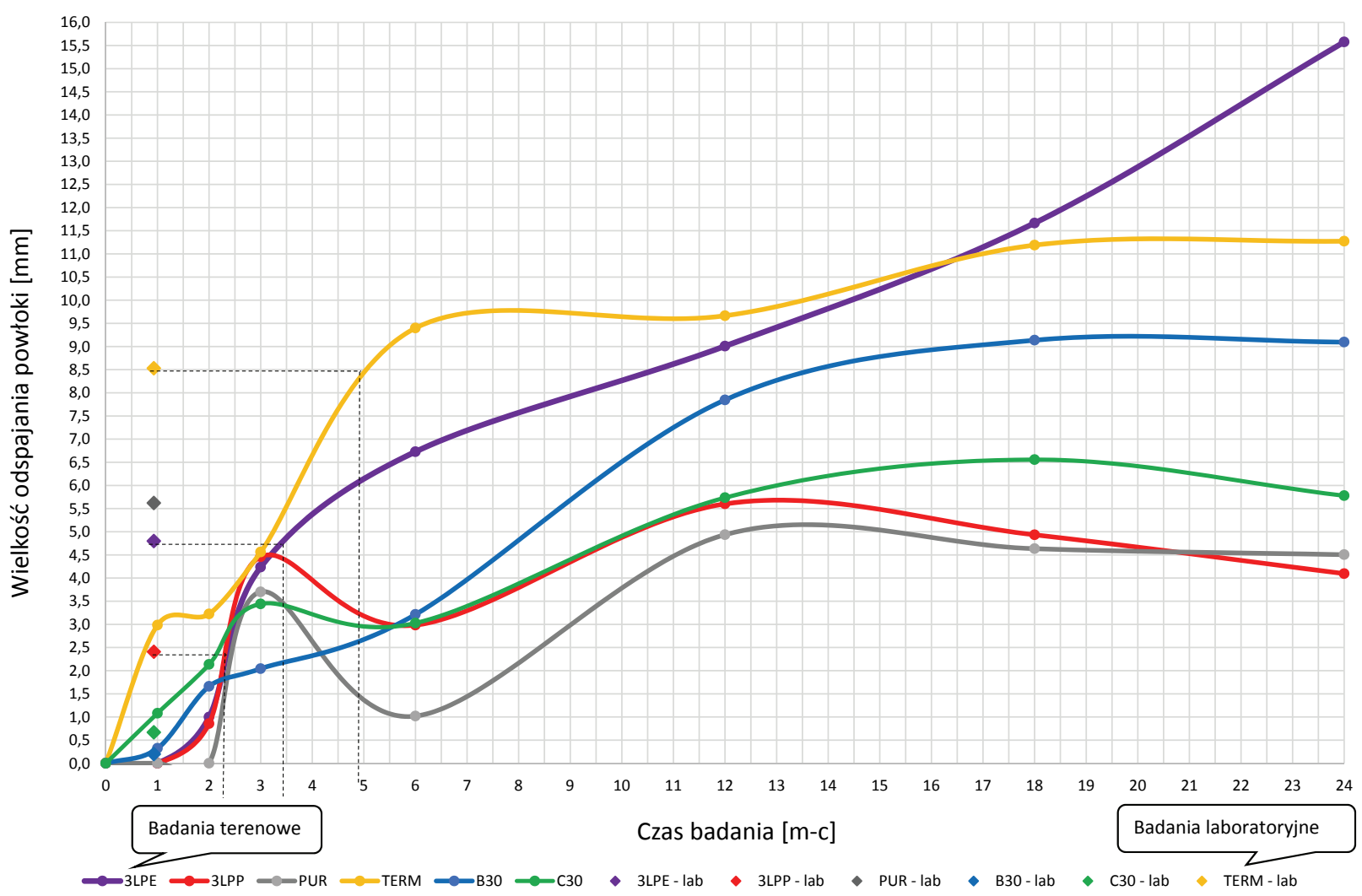

Rys. 4. Porównanie średnich wyników odspajania katodowego po 28-dniowych badaniach laboratoryjnych i 24-miesięcznych badaniach terenowych

Fig. 4. Comparison of the average results of cathodic disbondment after 28 days of laboratory tests and 24 month field tests

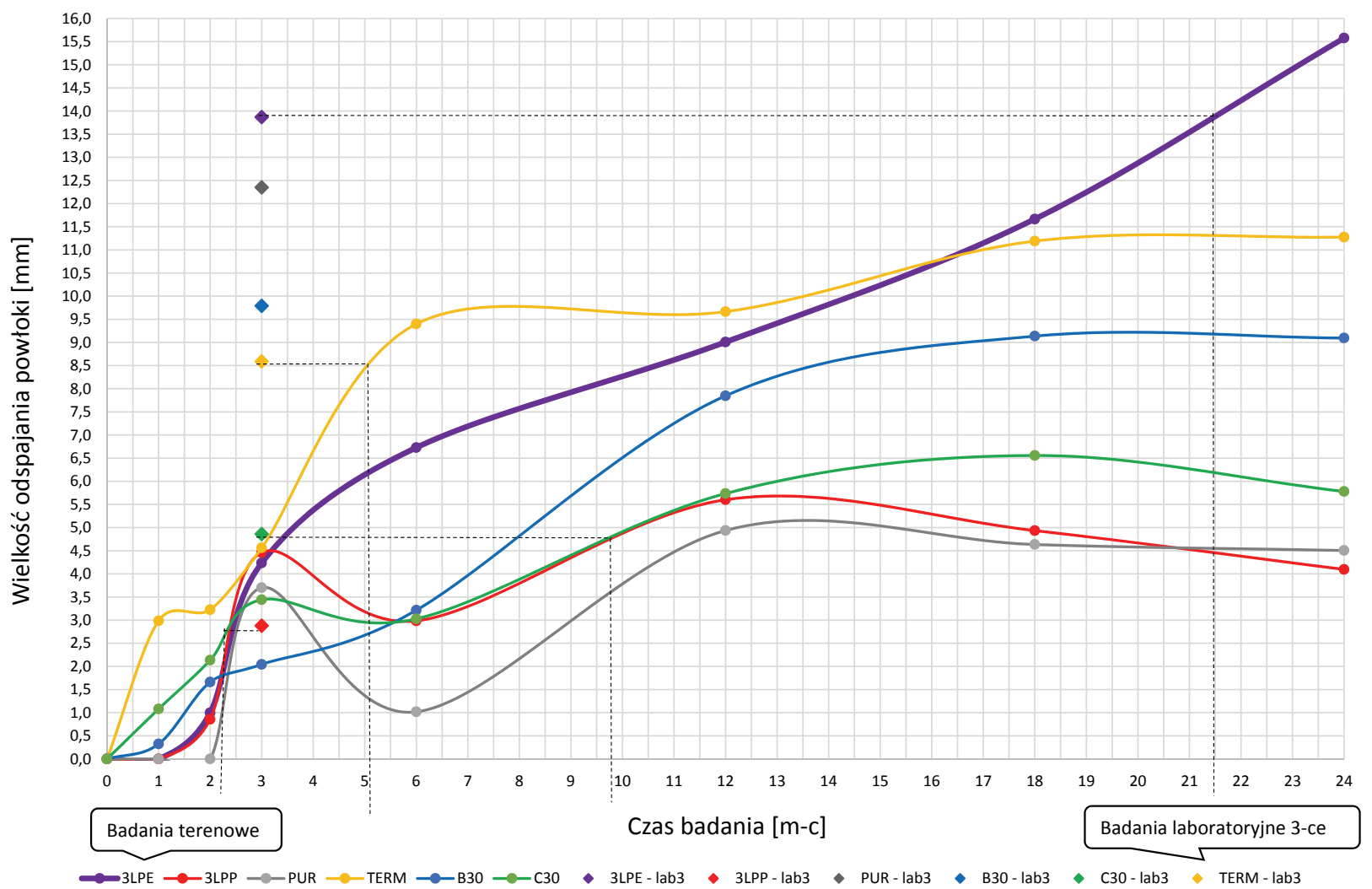

Rys. 5. Porównanie średnich wyników odspajania katodowego po 3-miesięcznych badaniach laboratoryjnych i 24-miesięcznych badaniach terenowych

Fig. 5. Comparison of average cathodic disbondment results after 3-month laboratory tests and 24-month field tests 
Na rysunku 5 przedstawiono średnie wyniki badań odspajania katodowego powłok uzyskane podczas 3-miesięcznych badań laboratoryjnych i 24-miesięcznych badań terenowych.

Wyniki badań laboratoryjnych i terenowych przedstawione w tabeli 1 oraz na wykresach 1, 2 i 3 są wynikami średnimi wielkości odspajania katodowego powłoki uzyskanymi podczas badań. W przypadku 4 z 6 typów powłok zauważono wyraźny wzrost wartości odspajania katodowego po 3-miesięcznych badaniach laboratoryjnych względem badań przeprowadzonych w okresie 28 dni. Jest to spodziewana sytuacja, gdyż zwiększenie czasu narażania z 28 dni do 3 miesięcy podczas badań laboratoryjnych miało na celu spowodowanie wzrostu wielkości odspajania katodowego w celu porównania wyników badań laboratoryjnych do wyników badań terenowych. Dzięki temu dla powłok 3LPE i C30 można odnotować znaczny wzrost przybliżonych czasów uzyskania wartości odspajania katodowego. W przypadku powłoki C30 możliwe stało się odczytanie przybliżonego czasu uzyskania wartości odspajania katodowego dla badań terenowych w porównaniu do 28-dniowych badań laboratoryjnych. Dla powłoki B30 (rys. 5) wartości odspajania katodowego po 3-miesięcznych badaniach laboratoryjnych są zbliżone względem badań terenowych po około 18 miesiącach, jednak wyniki badań nie są zbieżne. Powłoka PUR mimo wydłużenia okresu badań laboratoryjnych nie uzyskała zbieżnych wartości z wynikami badań terenowych.

Po okresie 3-miesięcznych badań laboratoryjnych dla powłok 3LPE i PUR zostały przekroczone dopuszczalne wartości odspajania katodowego. Świadczy to o tym, że te powłoki oznaczają się dużymi wartościami odspajania katodowego w określonym czasie pracy w warunkach terenowych względem pozostałych powłok. Może to stanowić pomocną informację dla operatorów rurociągów eksploatujących te typy powłoki.

\section{Wnioski}

W badaniach terenowych i laboratoryjnych nad zjawiskiem odspajania katodowego pod wpływem nadmiernej polaryzacji katodowej powłoki osiągnięto cel pracy, jakim było porównanie wyników badań laboratoryjnych i terenowych. Podjęta próba porównania uzyskanych wyników badań laboratoryjnych z otrzymanymi wynikami terenowymi podczas normalnej eksploatacji powłoki zakończyła się powodzeniem. Uzyskano wyniki badań laboratoryjnych i terenowych, w których wspólną cechą obu stanowisk badawczych był stały potencjał polaryzacji $-1500 \mathrm{mV}$.

Wyniki badań laboratoryjnych wykonanych zgodnie z odpowiednią dla badanej powłoki normą (PN-EN ISO 21809-1:2011;
PN-EN 10290:2005; PN-EN 12068:2002) można odnieść do badań wykonanych w warunkach eksploatacyjnych, w których badana powłoka będzie pracować.

1. Zastosowana metoda badawcza odzwierciedla zjawisko odspajania katodowego uszkodzonych powłok w realnych warunkach terenowych. Nadaje się do badań każdego typu powłok niemetalicznych. Do pomiaru wielkości odspojenia katodowego użyto tych samych metod i przyrządów pomiarowych.

2. 24-miesięczne badania terenowe wykazały stały przyrost średnich wartości odspajania katodowego. Przyrosty badanych typów powłok się różnią. Jest to spowodowane różną siłą adhezji dla poszczególnych typów powłok. Przygotowanie powierzchni stalowej rury do nałożenia powłoki ma zasadniczy wpływ na wartość adhezji powłoki.

3. Zastosowana metoda badań pozwoliła na porównanie wyników badań laboratoryjnych i terenowych. Dotychczas, wykonując badania laboratoryjne wielkości odspajania katodowego, nie można było porównać uzyskanych wartości do warunków rzeczywistych, w jakich badana powłoka jest eksploatowana. To znaczy, że jeśli podczas normalnej eksploatacji powłoki została ona uszkodzona, operator nie miał dotychczas wystarczającej wiedzy o zdolności powłoki do odspajania.

4. Zastosowana metoda mogłaby zostać wykorzystana do kompleksowego przebadania powłok w warunkach terenowych przy zastosowaniu różnego rodzaju gruntów i warunków narażania nadmiernym potencjałem katodowym. Metoda ta może również posłużyć operatorom do określenia czasu reakcji na ewentualne skutki uszkodzeń powłoki podczas eksploatacji. Jeśli przed zainstalowaniem danego typu powłoki w danym typie gruntu i w określonych warunkach eksploatacyjnych operator będzie czerpał wiedzę o spodziewanej wielkości odspajania katodowego, to będzie mógł określić wielkość zagrożenia korozyjnego i oszacować ryzyko z tym związane.

Artykuł powstał na podstawie pracy statutowej pt.: Analiza zjawiska odspajania katodowego powłoki na podstawie badań terenowych oraz badań laboratoryjnych - praca INiG - PIB na zlecenie MNiSW; nr zlecenia: 0053/GP/17/01, nr archiwalny: DK-4100-53/18.

\section{Literatura}

Baeckmann W., Schwenk W., Prinz W., 1997. Handbook of Cathodic Corrosion Protection Theory and Practice of Electrochemical Protection Processes. Third Edition. Gulf Professional Publishing. Dietrich A., 2009. Ocena ryzyka w transporcie gazu rurociągami. Nafta-Gaz, 3: 248-254.

Dietrich A., Badowski J., 2009. System komputerowy oceny stanu technicznego i analizy ryzyka dla dystrybucyjnych sieci gazowych. Nafta-Gaz, 11: 895-900. 
Li Z., Gan F., Mao X., 2002. A study on cathodic protection against crevice corrosion in dilute $\mathrm{NaCl}$ solutions. Corrosion Science, 44: 689-701.

Luo J.L., Lin C.J., Yang Q., Guan S.W., 1997. Cathodic disbanding of a thick polyurethane coating from steel in sodium chloride solution. Progress in Organic Coatings, 31: 289-295.

\section{Akty prawne i normatywne}

ASTM G19 Standard Test Method for Disbonding Characteristics of Pipeline Coatings by Direct Soil Burial.

PN-EN 10290:2005 Rury stalowe i łączniki na rurociągi przybrzeżne i morskie - Powłoki zewnętrzne z poliuretanu lub poliuretanu modyfikowanego nanoszone w stanie ciekłym.

PN-EN 12068:2002 Ochrona katodowa - Zewnętrzne powłoki organiczne stosowane łącznie $\mathrm{z}$ ochroną katodową do ochrony przed korozją podziemnych lub podwodnych rurociągów stalowych - Taśmy i materiały kurczliwe.

PN-EN 12954:2004 Ochrona katodowa konstrukcji metalowych w gruntach lub w wodach - Zasady ogólne i zastosowania dotyczące rurociągów.
PN-EN ISO 8501-1:2008 Przygotowanie podłoży stalowych przed nakładaniem farb i podobnych produktów - Wzrokowa ocena czystości powierzchni - Część 1: Stopnie skorodowania i stopnie przygotowania niepokrytych podłoży stalowych oraz podłoży stalowych po całkowitym usunięciu wcześniej nałożonych powłok.

PN-EN ISO 21809-1:2011 Powłoki zewnętrzne rurociągów podziemnych i podmorskich stosowanych w rurociągowych systemach transportowych - Część 1: Powłoki poliolefinowe (3-warstwowe PE i 3-warstwowe PP).

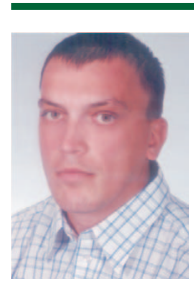

Mgr inż. Paweł STOCHAJ

Główny specjalista inżynieryjno-techniczny

w Zakładzie Przesyłania i Dystrybucji Gazu Instytut Nafty i Gazu - Państwowy Instytut Badawczy ul. Lubicz 25 A

31-503 Kraków

E-mail: pawel.stochaj@inig.pl

\section{OFERTA BADAWCZA ZAKŁADU PRZESYKANIA I DYSTRYBUCJI GAZU}

badania rur, ksztattek i armatury z tworzyw sztucznych stosowanych do budowy sieci gazowych, wodociągowych oraz do ciśnieniowej kanalizacji deszczowej i sanitarnej;

badania systemów przewodów rurowych do instalacji wody cieptej i zimnej wewnatrz budynków np. PE-X/Al/PE-X, PP, PB, PE-X badania armatury metalowej do sieci i instalacji gazowych oraz wodociągowych;

badania armatury do instalacji centralnego ogrzewania i solarnych;

badania armatury sanitarnej, np. baterii mechanicznych, termostatycznych; mieszaiących, zaworów wypływowych, natrysków i przewodów natryskowych;

badania reduktorów średniego ciśnienia;

badania powtok ochronnych z tworzyw sztucznych na rurach i armaturze stalowej;

ocena stopnia zagrożenia korozyjnego gazociagów stalowych oraz ocena stanu technicznego izolacji gazociagów stalowych metodami bezwykopowymi:

analiza zagrożeń korozyjnych na tłoczniach i magazynach gazu oraz instalacji związanych z ropociągami, wodociągami i podziemnymi zbiornikami;

ocena efektywności metod rekonstrukcii sieci dystrybucyinych gazu;

badania z zakresu wspótpracy ośrodka gruntowego z siecią gazową na terenach górniczych;

opiniowanie projektów przepisów oraz norm związanych z budową i użytkowaniem sieci gazowych;

prowadzenie specjalistycznych szkoleń z zakresu budowy sieci gazowych z polietylenu z zastosowaniem technologii zgrzewania doczotowego i elektrooporowego:

szkolenie i kwalifikacja personelu zgrzewającego rury i kształtki z PE wg PN-EN 13067 w INiG-PIB jako Ośrodku Szkoleniowym i Egzaminacyjnym uznanym przez UDT-CERT:

ocena jakości połączeń zgrzewanych rur i kształtek z PE na potrzeby kwalifikacji personelu zgrzewajacego wg normy PN-EN 13067 w Laboratorium Tworzyw Sztucznych uznanym przez UDT

wspomaganie przemystu we wdrażaniu nowych rozwiązań technicznych oraz opracowywanie ekspertyz i analiz.

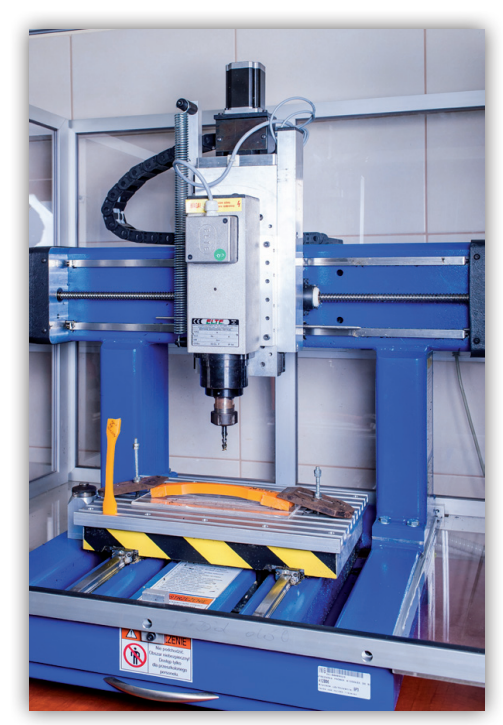

INSTYTUT NAFTY I GAZU

- Państwowy Instytut Badawczy 